\title{
ANALISIS KETERTARIKAN GENERASI MILENIAL UNTUK PERANCANGAN BATIK MALANGAN
}

\author{
Syafira Audianty ${ }^{1}$, Yan Yan Sunarya ${ }^{2}$ \\ 1. Program Studi Magister Desain, Fakultas Seni Rupa dan Desain, Institut Teknologi Bandung, \\ Jl. Ganesha No.10 Bandung, 40132, Indonesia \\ 2. Program Studi Doktor IImu Seni Rupa dan Desain FSRD ITB, Jl. Ganesha No.10 Bandung, 40132, Indonesia \\ syafaudi@gmail.com1, yanyan@fsrd.itb.ac.id2
}

\begin{abstract}
Motif is a creativity that is formed from the inspiration of the people who living in it, so it different from one place to another. malangan lotus flower batik motifs is one of the examples, but this icon and batik motif is still less desirable so there are efforts to popularize malangan batik. This design development is not only aims to produce new batik designs that are in accordance with local wisdom, but also has a social and economic impact. With ATUMICS method, it become an investment for the Malang area in the future. The revitalization is aimed to creating new batik designs for the millennials who are considered to have the power to boost the regional economy and wealth. This research aims to analyze and understand the millennial's interest in traditional batik and the development of Malang lotus flower batik to create new batik designs. The analysis includes the millennial generation's interest in visuals and batik fashion products. The research method used is a qualitative method. It is to obtain literature studies and to get the millennial respondents. From this research, it can be concluded that the visual and design product are important variables in the development of new design batik malangan lotus flower, so that it can be a reference in increasing commercial value and attractiveness to the community.
\end{abstract}

Keywords: Batik, Local Wisdom, Lotus, Malang, Millennial Generation.

\begin{abstract}
ABSTRAK
Motif adalah sebuah kreatifitas yang terbentuk dari inspirasi masyarakat yang mendiaminya, sehingga berbeda-beda antara satu tempat dengan yang lainnya. Salah satunya adalah motif batik bunga teratai malangan, namun ikon dan batik ini masih kurang memiliki daya tarik sehingga, muncul upaya untuk mempopulerkan Batik malangan. Keterbaruan desain ini tidak hanya bertujuan untuk menghasilkan batik desain baru yang sesuai dengan kearifan lokal daerah. Dengan metode ATUMICS hal ini juga berdampak pada sosial dan ekonomi untuk menjadi investasi daerah Malang kedepannya. Upaya revitalisasi ini ditujukan untuk menciptakan batik desain baru untuk generasi milenial yang dianggap memiliki kekuatan untuk mendorong ekonomi dan kekayaan daerah. Penelitian ini bertujuan untuk menganalisis dan memahami ketertarikan generasi milenial terhadap batik tradisional dan pengembangan batik bunga teratai malangan untuk menciptakan perancangan batik desain baru. Analisis tersebut meliputi ketertarikan generasi milenial terhadap visual dan produk olahan batik. Penelitian ini merupakan jenis penelitian kualitatif untuk mendapatkan studi literatur dan didukung melalui kuesioner kepada responden untuk mengetahui ketertarikan generasi milenial. Dari penelitian ini dapat disimpulkan bahwa visual dan desain produk batik adalah variabel yang penting dalam pengembangan batik desain baru bunga teratai malangan, sehingga dapat menjadi acuan dalam meningkatkan nilai komersil dan daya tarik bagi masyarakat.
\end{abstract}

Kata Kunci: Batik, Generasi Milenial, Kearifan Lokal, Malang, Teratai. 


\section{PENDAHULUAN}

Upaya pelestarian dengan memperhatikan kearifan lokal bertujuan sebagai pedoman kehidupan bagi masyarakat. Selain itu dapat juga menjadi strategi adaptif dalam menyiasati perkembangan zaman, isu permasalahan untuk memenuhi kebutuhan hidup dan mempertahankan bahkan bertambah nilainya (Rohidi, 2000:6-7). Kearifan lokal menjadi landasan awal untuk melangkah dan menyusun strategi pengembangan desain yang lebih terarah dan tidak menyalahi aturan. Pada kearifan lokal Kota Malang, banyak terinspirasi dari kehidupan masyarakat sejak turun-temurun. Hal ini dapat dilihat dari kerajinan batik malangan yang semua motifnya terinspirasi dari dan ada di daerah Malang (Hermawati, 2017). Salah satunya julukan Kota Bunga dengan ikon bunga teratai malangan yang menjadi inspirasi masyarakat.

Motif batik bunga teratai malangan sampai saat ini belum begitu populer di kalangan masyarakat. Padahal motif ini melambangkan suatu keindahan alam yang penuh kesuburan dan erat dengan kerajaan Singasari yang menjadi cikal bakal budaya Malang dan nilai kedaerahannya (Hermawati, 2017). Upaya pelestarian batik malangan termasuk motif bunga teratai terus diupayakan dengan tujuan untuk mempopulerkan, memberi inovasi, dan menjadi wadah kreatifitas sebagai kekayaan kerajinan batik Kota Malang. Hal ini juga selaras dengan batik juga harus dapat menjadi solusi atas permasalahan yang ada dan relevan dengan semangat zaman (Sunarya, 2014). Keterbaruan dalam inovasi pengembangan batik dapat berupa visual, material, teknik, gaya, dan fungsinya sehingga dapat menciptakan batik desain baru yang menarik untuk konsumen (Kodiya, 2016).

Dalam pengembangan batik ini, pemerintah turut memiliki harapan besar pada konsumen generasi milenial. Generasi milenial dipercayai memiliki potensi besar untuk perekonomian, UMKM, dan juga daya beli produk dalam negeri (Herman dalam Berita Satu, 2020). Pola kebiasaan milenial yang dekat dengan sikap konsumtif, trend-setter dalam teknologi, gaya hidup, dan fashion (Yuswohady, 2016) erat dengan tujuan pemerintah untuk mendukung ekonomi di sektor UMKM. Untuk dapat meningkatkan kerajinan batik bunga teratai malangan ini, perlu disesuaikan juga dengan ketertarikan generasi milenial meliputi visual pada batik sehingga memiliki nilai komersil dan daya tarik yang lebih baik dari sebelumnya.

Penelitian ini berperan dalam melakukan pengembangan terhadap kerajinan batik desain baru untuk dapat mengangkat kembali potensi daerah Malang dengan motif bunga teratai malangan. Pengembangan kerajinan batik bunga teratai malangan ini didasari dengan menganalisis ketertarikan target konsumen generasi milenial yang dianggap mampu membantu meningkatkan nilai komersil dan daya tarik kerajinan lokal. Dengan begitu penciptaan pengembangan produk kerajinan batik malangan 
ini selain sebagai upaya meningkatkan kearifan lokal juga harus mampu menarik target sasaran salahsatunya dari aspek visual. Penelitian ini bertujuan untuk menemukan peleburan antara kearifan lokal daerah Malang dengan keinginan pasar generasi milenial untuk membantu keanekaragaman batik, ekonomi, dan sosial setempat.

\section{METODE PENELITIAN}

Jenis penelitian ini adalah penelitian kualitatif deskriptif. Kualitatif pada penelitian ini dilakukan dengan studi literatur untuk mempelajari mengenai masyarakat Malang, bunga teratai malang, batik malangan, produk fashion, teori estetika, revitalisasi desain, dan metode ATUMICS yang menjadi landasan awal dalam menganalisis penelitian.

Didukung dengan kuesioner kepada generasi milenial untuk mendapatkan informasi mengenai pengetahuan batik malangan dan potensi pengembangan produknya. Penelitian ini memfokuskan pada ketertarikan generasi milenial terhadap visual batik malangan meliputi motif, bentuk, warna, komposisi, teknik, dan desain produk. Turut pula didukung dengan menganalisis potensi pemasaran dan daya beli generasi milenial sebagai upaya mendekatkan kerajinan batik malangan.

Hasil dari penelitian ini akan dijelaskan secara deskriptif mengenai ketertarikan generasi milenial sebagai inspirasi dalam pengembangan batik desain baru untuk daerah Malang yang memiliki nilai komersil dan daya tarik yang lebih baik. Dengan begitu dapat menjadi potensi baru pada sektor kerajinan tekstil, ekonomi untuk UMKM dan pemasaran untuk nilai komersil kedepannya.

\section{HASIL DAN PEMBAHASAN \\ Revitalisasi dan ATUMICS}

Proses revitalisasi tradisi pada sebuah kawasan mencangkup perbaikan pada aspek fisik, ekonomi, atau sosial, serta harus mampu mengenali dan memanfaatkan potensi lingkungan (Danisworo, 2000). Menurut Laretna T. Adhisakti (1977), revitalisasi dapat diartikan sebagai kegiatan pembangunan, pengembangan, restorasi, replikasi, rekonstruksi dan atau penggunaan untuk fungsi baru dari suatu aset masa lalu. Elemen utama dari tradisi tersebut dapat direvitalisasikan dan tidak hanya berorientasi untuk penyelesaian keindahan fisik/ estetika, melainkan harus di lengkapi dengan upaya peningkatan ekonomi masyarakatnya serta pengenalan pada budaya yang ada.

Dalam proses pelestarian dengan meleburkan kekayaan tradisi dengan kondisi terkini, menurut Adhi Nugraha (2012) perlu memperhatikan enam hal yang terangkum dalam dengan metode ATUMICS yaitu:

\section{Shape}

Bentuk, sifat visual, dan fisik dari suatu objek, termasuk analisa ukuran dan proporsi.

\section{Material}

Material dibedakan menjadi dua, yaitu mate- 
rial tradisional dan material baru.

\section{Technique}

Pengetahuan mengenai cara pembuatan atau teknik dari suatu artefak dan pengembangannya.

4. Utility

Utility didefinisikan sebagai tujuan fungsional pada suatu benda.

5. Icon

Tanda simbolis atau ikonik dan makna tertentu pada suatu benda sesuai kepercayaan daerah.

\section{Concept}

Konsep dapat diukur secara kualitatis yang disepakati oleh kelompok tertentu.

Prinsip utama metode Artefact, Technique, Utility, Material, Icon, Concept, dan Shapeatau ATUMICS adalah tentang pengaturan, kombinasi, integrasi, atau campuran antara unsur-unsur dasar tradisi dengan modernitas (Nugraha, 2012:205).

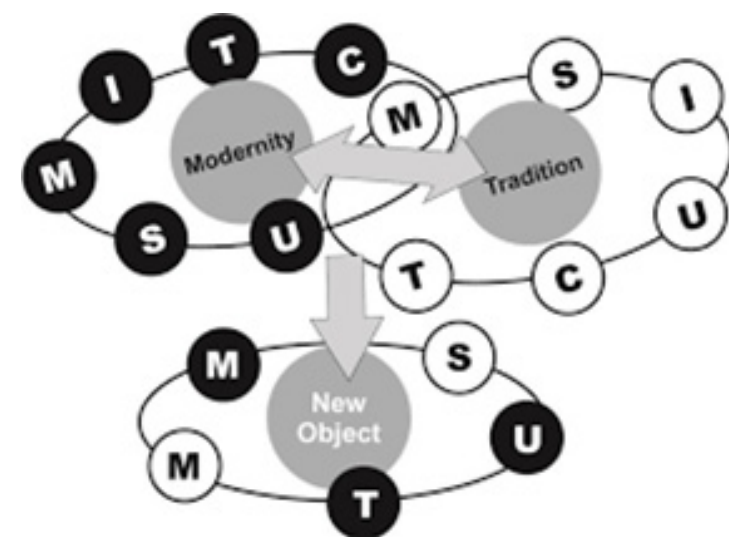

Gambar 1 Skema Proses Integrasi Antara Tradisi dan Modernitas (Nugraha, 2012)
Aspek lain yang membantu kegiatan revitalisasi adalah peran penggunaan teknologi informasi, khususnya dalam mengelola keterlibatan banyak pihak untuk membantu memperkenalkan dan mengingatkan kembali objek yang sebelumnya vital sehingga memiliki pemaknaan baru pada produk.

\section{Kearifan Lokal dan SDM Kota Malang}

Kota Malang merupakan daerah yang lahir akibat adanya industrialisasi massal pada abad ke-19 hingga ke-20 (Herdianto, 1996). Latar belakang ini juga turut andil dalam terbentuknya kebudayaan Malang. Faktor ini berperan erat dalam proses terbentuknya kesenian yang ada di kota ini. Julukan untuk kesenian yang dimiliki daerah Malang adalah malangan (Budiono, 2016:56).

Gaya ini menjadi inspirasi dalam mengembangkan kesenian salahsatunya dari julukan de Bloemenstad atau Kota Bunga yang diberikan oleh Belanda pada tahun 1992. Kota Bunga diartikan sebagai cita-cita dari setiap hati warga Kota Malang untuk senantiasa menyemarakkan kesegaran di tanah tinggalnya (Pemerintah Kota Malang, 2020)

Kesenian dan kearifan lokal Kota Malang merupakan kekuatan masyarakat untuk membangun potensi terbaiknya. Salahsatunya dengan upaya mendorong keberlangsungan Usaha Mikro Kecil dan Menengah (UMKM) serta menciptakan ekosistem dengan sangat baik 
(Bidang Informasi Publik Malang, 2019). Potensi sumber daya alam masih dapat dikembangkan lebih jauh karena dapat menjadi inspirasi dan dimanfaatkan dalam proses kesenian dan produk batik. Namun potensi sumber daya manusia atau pengrajin batik Kota Malang kian mengalami penurunan.

Pemanfaatan kearifan lokal oleh pengrajin / SDAdi Kota Malang dapat dilihat dengan menggunakan teknik batik tradisional dan pewarnaan alami yang motifnya terinspirasi dari lingkungan sekitar. Sehingga setiap UMKM memiliki hasil kerajinan batik khasnya sendiri.

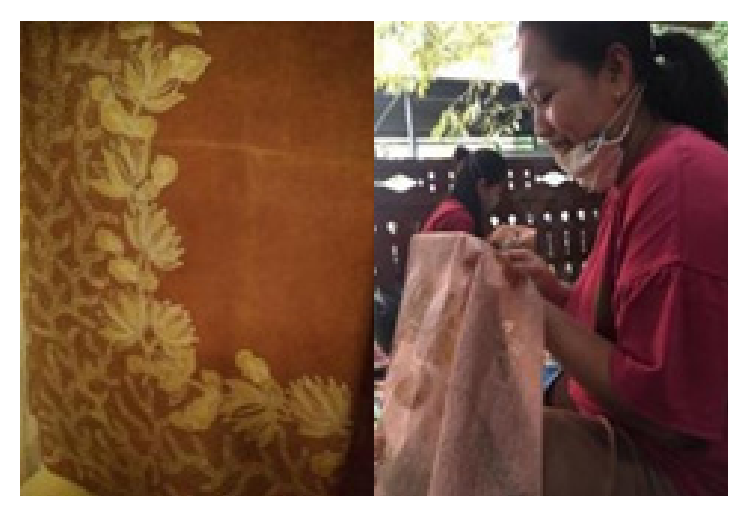

Gambar 2 Kearifan lokal dan Pengrajin Batik Malangan (Audianty, 2020)

Perkembangan UMKM dan inovasi yang diciptakan oleh pengrajin juga dapat dilihat dengan adanya inovasi pada teknik canting elektrik, batik cap, dan pewarna sintetis. Walaupun terdapat keterbatasan kreatifitas desain motif batik dari pengrajin juga, fungsi, dan konsep produk, namun UMKM dan pelaku usaha batik tetap berupaya menghasilkan kreatifitas khas masyarakat lokal sebagai upaya menjaga nilai daerah Kota Malang dan untuk memenuhi kebutuhan ekonomi.

Adanya UMKM dan pelaku usaha batik ini menjadi wadah berkumpulnya sekelompok orang yang memiliki ketertarikan dan keahlian yang sama dalam membatik. Sehingga terdapat upaya untuk menciptakan keterbaruan kerajinan dan atau produk batik sesuai yang kreatifitas, potensi, dan juga masyarakat yang berujung menciptakan keuntungan (Rosisim dkk., 2006)

\section{Batik Malangan}

Batik sebagai Warisan Kemanusaiaan untuk Budaya Lisan dan Non-bendawi seiring perkembangannya memiliki beberapa kateogri yaitu:

1. Batik Tradisional: Batik yang dikerjakan secara turun-temurun pada sekelompok masyarakat diiringi dengan meditasi dan tingkat religiusitas yang tinggi minya. (Anas, 1997:5 dalam Kodiya, 2016).

2. Batik Modern: Keberlangsungan batik akibat pergolakan yang bersifat teknis, estetis, normatif, ikonografis, simbolis, fungsional untuk menanggapi perubahan dengan adanya peleburan gaya (Anas, 1997: xiv dalam Kodiya, 2016).

3. Batik Desain Baru: Peracangan desain dengan menggunakan metode eksplorasi yang mengutamakan hal-hal berkaitan dengan aspek estetik dalam visual dengan maksud memadukan komposisi bentuk, teknik, material, dan warna dalam produk batik (Sachari, 2003:1 dalam Kodiya, 2016). 
Audianty, Sunarya

Batik dinyatakan sebagai medium berekspresi dengan keterampilan mengolah material, teknik, dan motif. Seperti halnya kerajinan batik Kota Malang yang setiap inspirasi dari kerajinan ini terinspirasi dari semua potensi di daerah Malang (Hermawati, 2017). Pembuatan batik malangan yang terinspirasi dari kearifan lokal merupakan wujud upaya meningkatkan kualitas hidup masyarakat didalamnya serta tetap menjaga identitas daerah. Kreatifitas pada batik dan segala bentuk proses didalamnya dimulai dengan bahan yang sederhana menggunakan canting dan malam. Munggunakan teknik batik tulis, hingga perkembangannya pada batik cap, dan inovasi canting elektrik yang timbul di masayarakat malangan.

Dengan perkembangan ini batik malangan memiliki beberapa motif, seperti pada Yusak Anshori dan Adi Kusrianto (2011) dalam bukunya yang berjudul Batik Keesksotisan Batik Jawa Timur: Memahami Motif dan Keunikannya menyebutkan macam-acam motif Malang Raya menyebutkan motif batik malangan.

Tabel 1 Batik Malangan (Anshori dan Kusrianto, 2011)
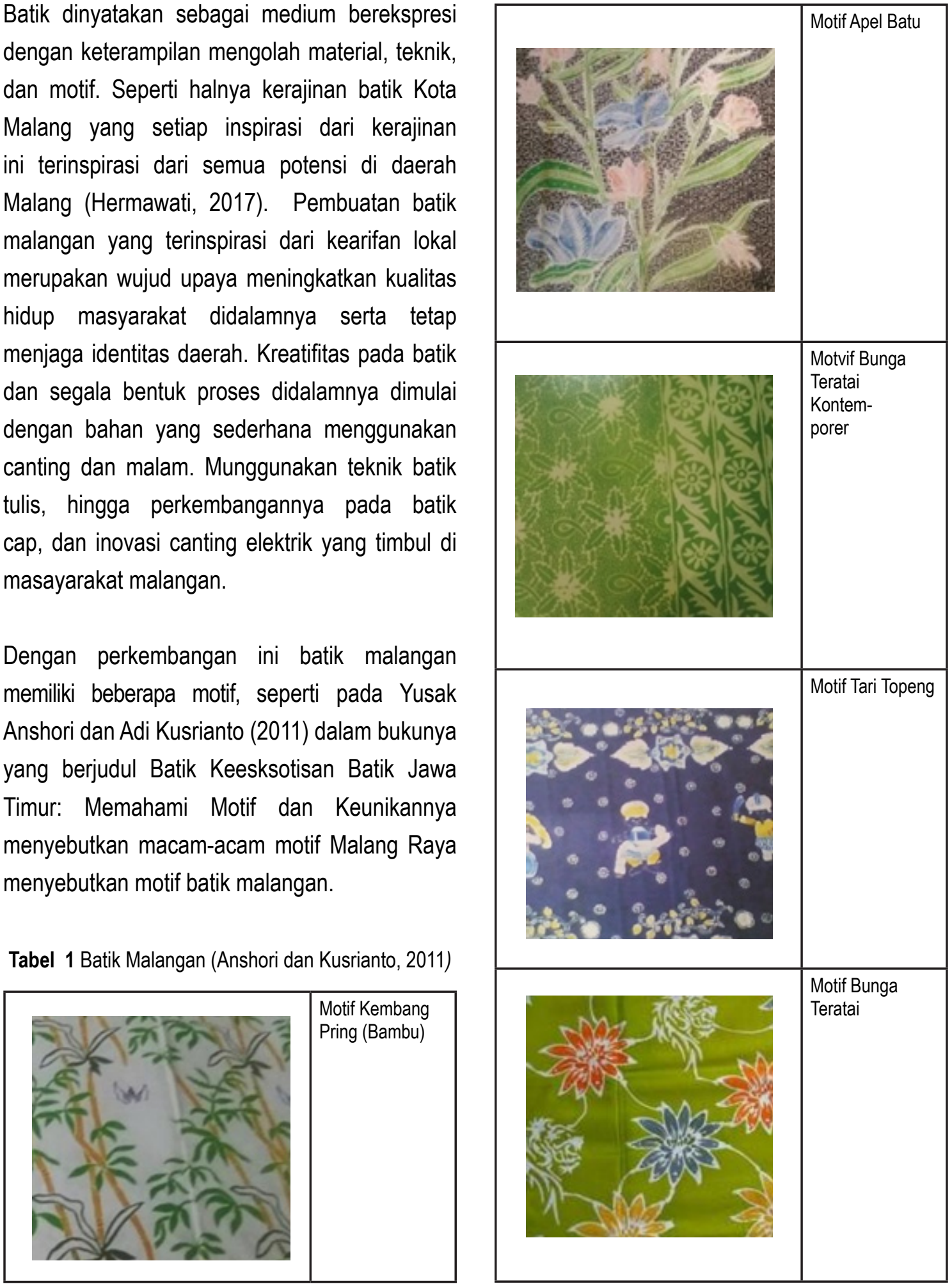
Kerajinan batik malangan dalam pengkembangan zaman dan bermasyarakat di implementasikan dalam beberapa kerajinan fungsional dan berubah menjadi upaya untuk memenuhi kebutuhan keseharian masyarakatnya. Hingga banyak dijadikan suatu komunitas untuk bekerja dan menambah penghasilan yang tergabung dalam UMKM.

\section{Batk Bunga Teratai Malangan}

Malang merupakan tempat lahir hingga tumpasnya kerajaan Singasari (Handinoto \& Soehargo, 1996:15) yang meninggalkan prasasti candi Singasari dan tercerminkan didalamnya bunga-bunga banyak tumbuh beraneka ragam. Salah satunya bunga teratai, bunga teratari ini melambangkan suatu keindahan alam yang penuh kesuburan (Hermawati, 2017).

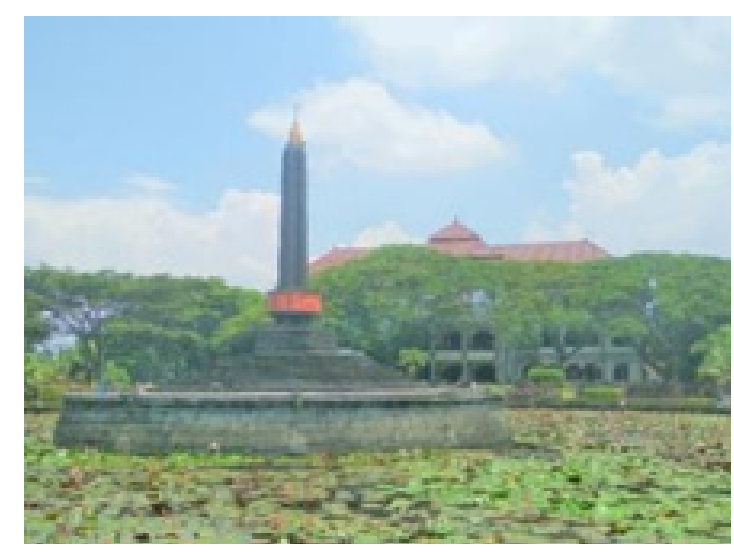

Gambar 3 Tugu Malangan (Audianty, 2020)

Bunga teratai sendiri merupakan tanaman air yang terkait erat dengan kedatangan HinduBuddha di Indonesia. Bunga teratai disebut sebagai tanaman suci dan dipopulerkan oleh kalangan bangsawan.
Dalam masa ini Teratai memiliki arti hati manusia yang memiliki beberapa lapisan mencerminkan sifat kejujuran dan kebohongan yang bersifat manusiawi (Kodiya, 2016). Selain itu, bagi Kota Malang bunga ini juga mengandung kebijaksanaan dan kearifan yang mampu memakmurkan masyarakat didalamnya (Hermawati, 2017). Pada perkembangan Kota Malang, bunga teratai banyak tumbuh di alunalun sebagai pusat kota dan menjadi ikon yang menginspirasi kekayaan tekstil dan kearifan lokal daerah.

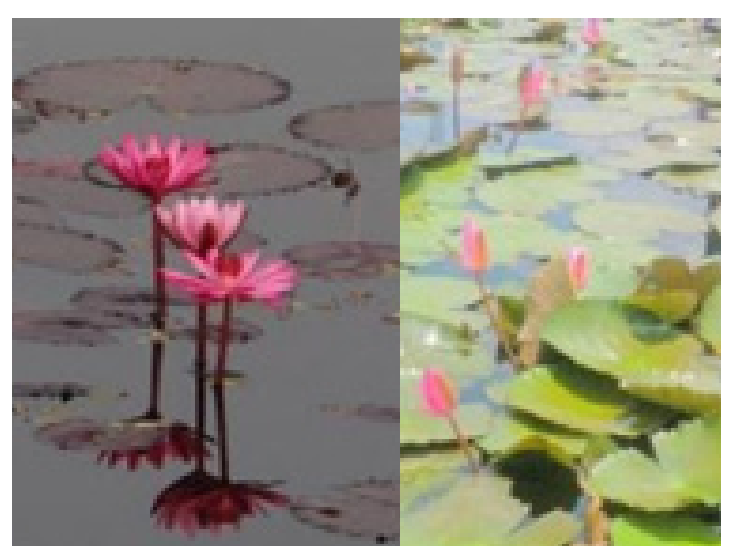

Gambar 4 Bunga Teratai di Tugu Malangan (Audianty, 2020)

Kekayaan tekstil motif ini tercermin dari adanya motif batik bunga teratai malangan. Motif floral yang menjadi ikon Kota Malang ini di adaptasi oleh masyarakat dari lingkungan sebagai kekayaan ragam hias flora untuk melambangkan Malang sebagai Kota Bunga (Anshori dan Kusrianto, 2011).

Potensi kerajinan batik menciptakan karya yang merepresentasikan kekayaan suatu 
Audianty, Sunarya

Analisis Ketertarikan Generasi Milenial Untuk Perancangan Batik Malangan

daerah. Selain itu upaya pelestarian ini juga berorientasi kepada masa depan dengan bentuk baru dan identitas modern yang selaras dengan kekinian, seperti pada kearifan lokal dibidang kriya (Anas, 2007). Dibuktikan dengan adanya upaya pengembangan motif bunga teratai malangan yang dibuat oleh pengrajin dan UMKM Kota Malang dimasa kini.
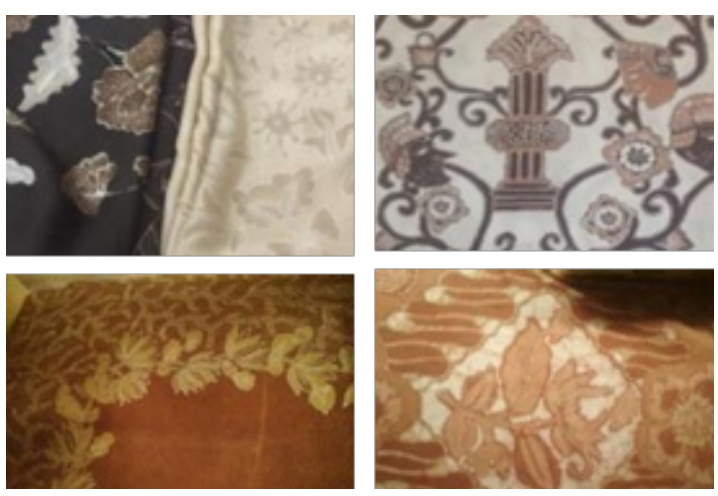

Gambar 5 Kreasi Batik Bunga Teratai Malangan di Batik Organic Buring Malang (Audianty, 2020)

Bunga teratai malangan menjadi bukti kreatifitas masayarakat yang dituangkan dalam wadah batik sebagai tekstil dan kriya. Sehingga inspirasi motif ini mampu mendorong kerajinan batik lokal.
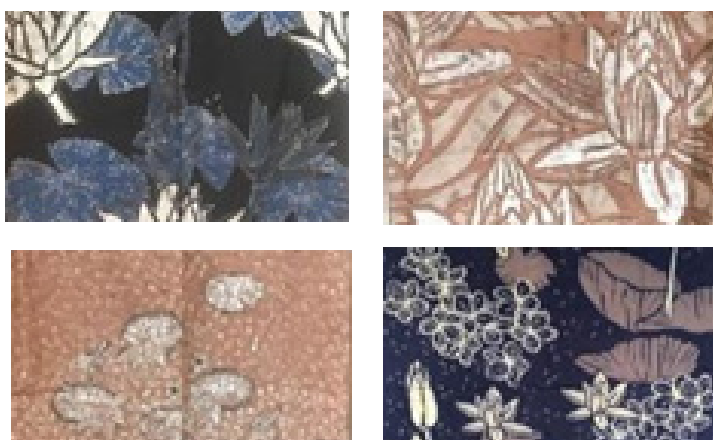

Gambar 6 Pengembangan Batik Bunga Teratai Malangan Tahap 1 (Audianty, 2020)

\section{Estetika pada Batik}

Estetika meliputi segala bentuk dan hal yang berkaitan dengan keindahan visual. Hal tersebut dapat ditemukan pada ragam hias yang melingkupi corak, warna, bentuk, komposisi, media, teknik, gagasan, serta material.

Konsep estetika saat ini berkembang, mencangkup masalah penilaian, tingkah laku, pengalaman, dan kesenangan (Gaut dan Lopes, 2000). Keindahan membuaat manusia merasakan, mengingat, dan terpesona hingga dapat menimbulkan rasa keinginan untuk mengalami perasaan tersebut kembali. Visual yang menarik dapat menimbulkan rasa senang, nyaman, bahagia, dan puas saat pengamat atau penikmat mengamati suatu produk atau benda, sehingga terdapat dorongan untuk memiliki dan menginginkan produk tersebut (Djelantik, 1999:73).

Dengan begitu estetika visual berkaitan erat dengan upaya mempengaruhi ketertarikan dan nilai komersil pada produk batik dan kerajinan yang ingin di pasarkan. Tiga aspek estetik mendasar dalam suatu seni yang terelaborasi dengan batik yaitu:

a. Wujud atau rupa (appearance): wujud dan rupa dalam batik diistilahkan sebagai ragam hias atau corak (Kodiya, 2016).

b. Bobot atau isi (content, substance): isi ini diartikan sebagai sesuatu yang dapat ditangkap oleh indera seperti hal atau objek apa yang ingin di pertegas dalam batik (Kodiya, 2016). 
c. Penampilan atau penyajian (Presenattion): Penyajian dan penyajian ditujukan untuk menampilkan karya batik kepada pengamat batik serta masyarakat umum (Kodiya, 2016).

Keindahan dalam wujud dan rupa pada ragam hias batik dapat dijabarkan menjadi: ragam hias/corak, warna, bentuk, komposisi, media, teknik, gagasan, serta material (Sunarya, 2014). Hal ini juga berpengaruh pada penilaian estetik batik untuk gaya berbusana modern dan tradisional.

\section{Kriya Tekstil}

Kriya dapat dijelaskan sebagai nilai dan gagasan budaya yang terpendam dalam fikiran masyarakatnya dan dituangkan dalam sebuah kerajinan mencakup pengetahuan dan keahlian yang bertumpu pada keterampilan dan penguasaan medium, yang kini bersifat multiinter-transdisiplin dan kontekstual (Sunarya 2017). Keterkaitan erat antara kriya dengan sejarah, lingkungan, dan tradisi masyarakat penciptanya; menunjukkan pengertian dialektis dengan modernitas yang bersifat dinamis dalam kontelasi kemajuan semangat zaman.

Kriya menjadi konteks kreatifitas budaya yang didasari atas kegiatan eksperimentasi dan eksplorasi terhadap keunggulan dan keunikan dari material menjadi karya baru. Karya kriya harus dapat memiliki relevansi dengan zaman sekarang dan dapt digunakan untuk menjawab sebagian dari tantangan zaman dan isu kehidupan masyarakat. Dapat dilakukan dengan proses perubahan dan refungsionalisasi (Sunarya, 2014). Pengembangan produk kriya tekstil dapat dibentuk menjadi produk fashion untuk menambah nilai guna dan nilai komersil pada pasar sehingga turut serta tanggap dalam dinamika perubahan yang ada.
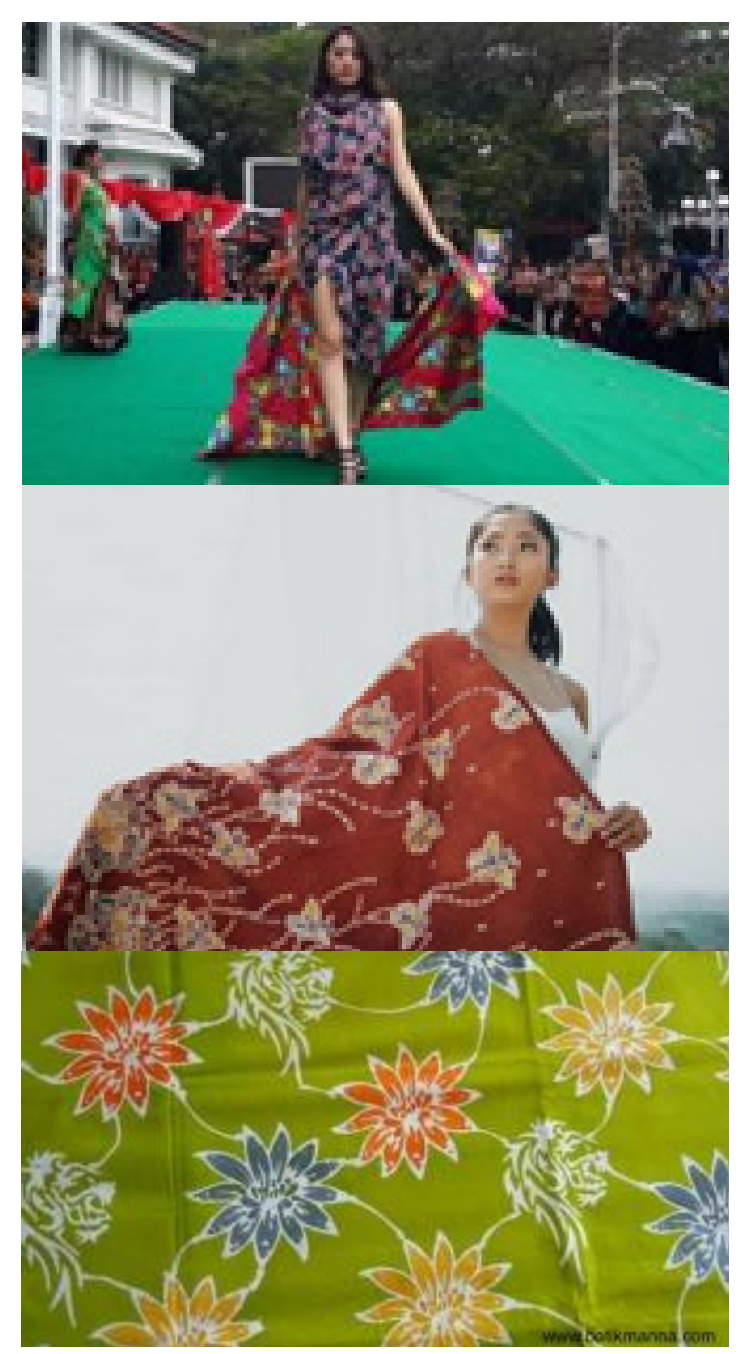

Gambar 7 Produk Tekstil dan Fashion Batik Blimbing Malang (Instagram.com/batikblimbing) 
Mode pada fashion tidak terlepas dengan penggunana bahan atau tekstil seperti batik. trend fashion pada suatu masa disetiap kalangan memiliki gaya dan kesukaan yang berbeda-beda. Hal ini diperkuat dengan adanya segmentasi pada sebuah komunitas dan masyarakat tertentu. Fashion menjadi sebuah wadah, aksesibilitas, dan distribusi produk untuk mengembangkan kriya tekstil dan batik bersama pelaku usaha dan pengrajin untuk diterima oleh masyarakat seperti olahan tekstil batik bunga teratai malangan. Produk fashion ini membantu meningkatkan nilai guna dan komersil untuk konsumen terhadap batik itu sendiri.

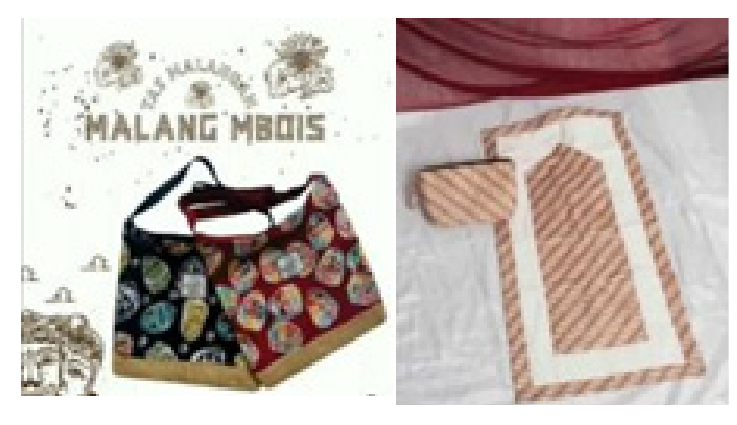

Gambar 8 Olahan Batik Tas Malang Mbois (Instagram.com/malangmbois.id)

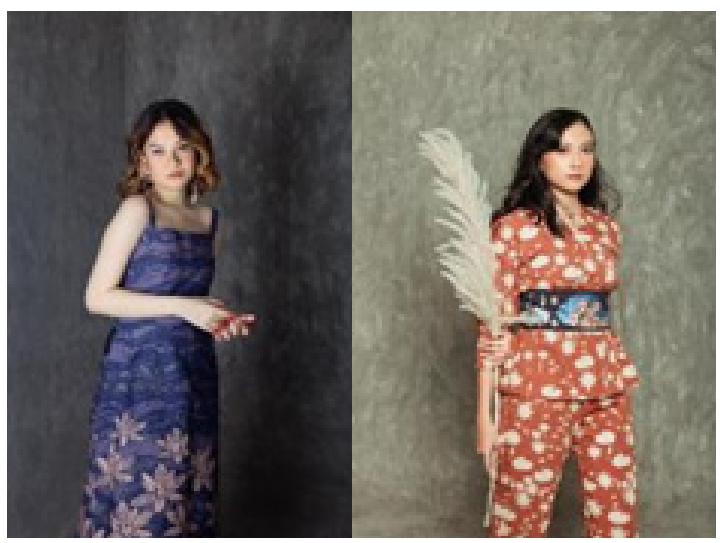

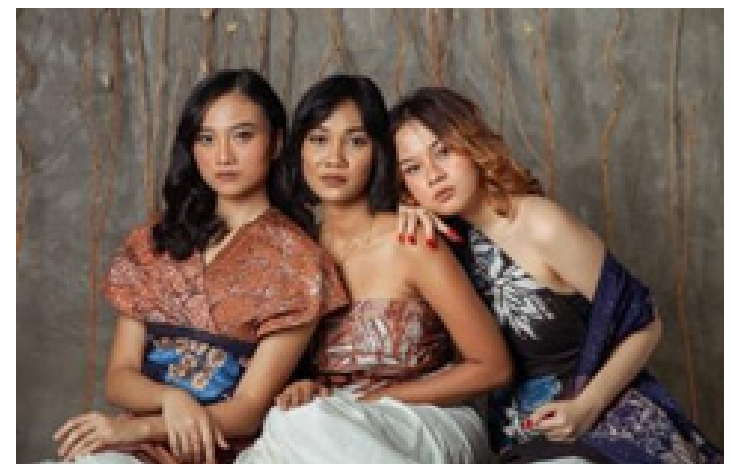

Gambar 9 Produk fashion dan textile pengembangan tahap 1 (Audianty, 2020)

\section{Generasi Milenial}

Generasi dikelompokan berdasarkan kesamaan tahun kelahiran, umur, lokasi, dan kejadiankejadian dalam kehidupan kelompok individu tersebut yang memiliki pengaruh signifikan dalam fase pertumbuhan mereka (Kupperschmidt, 2000).

Faktor utama dalam pengelompokan generasi yaitu kesamaan tahun kelahiran dan sosiologis khususnya kejadian historis yang melekat pada masa perkembangannya (Parry \& Urwin, 2011). Terdapat pula atribut pendukung yang mengelompokan generasi milenial yaitu:

1. Perceived membership: persepsi individu terhadap sebuah kelompok dimana mereka tergabung didalamnya.

2. Common belief and behaviors: sikap terhadap keluarga, karir, kehidupan personal, politik, agama, dan pilihan-pilihan yang diambil terkait dengan pekerjaan, pernikahan, anak, kesehatan, dan kejantanan.

3. Common location in history: perubahan pandangan politik, kejadian yang bersejarah 
Lancaster \& Stillman dalam When Generation Collide (2002) mengelompokan generasi milenial atau $Y$ adalah kelompok individu yang lahir pada tahun 1981-1999. Hal ini juga diperkuat oleh Yuswohady dalam artikel Millennial Trend (2016), generasi milenial merupakan sekelompok orang yang lahir pada rentang waktu 1981 hingga akhir 1990. Di Indonesia sendiri kelompok ini terbentuk dengan kesamaan peristiwa, pola dan perkembangan komunikasi, dan juga pandangan terhadap politik, sosial, dan ekonomi yang mempengaruhi masa perkembangannya.

Milenial atau millennium merupakan generasi yang banyak menggunakan teknologi komunikasi instan seperti email, SMS, instan messaging, dan aktif dalam perkembangan sosial media seperti facebook, twitter, Instagram. Generasi ini tumbuh dalam era internet booming (Lyons, 2004).

Milenial memiliki pola komunikasi yang sangat terbuka dibandingkan generasi-generasi sebelumnya, dapat dilihat dengan penggunaan sosial media yang fanatik serta kehidupannya yang sangat terpengaruh dengan perkembangan teknologi. Generasi milenial menjadi generasi yang terbuka dan konsumtif sehingga banyak dianggap sebagai trend-setter karena selalu menjadi yang terdepan dari setiap perkembangan gaya hidup, gadget, atau fashion dan dapat mempengaruhi beberapa generasi lainnya (Yuswohady, 2016).

\section{Segmentasi Pengembangan}

\section{Produk Batik untuk Generasi Milenial}

Pengembangan produk batik dilakukan dengan menentukan target pasar generasi milenial yang dijelaskan dalam beberapa segmentasi yaitu:

\section{Segmentasi Demografis}

Perempuan dan laki-laki antara umur 21 hingga 41 tahun. Tingkat Pendidikan S1-S3, pekerjaan sebagai mahasiswa, desainer, pegawai swasta, freelancer atau pekerja seni lainnya.

2. Segmentasi Geografis

Generasi milenial yang merupakan Warga Negara Indonesia (WNI) dan pernah atau tinggal di perkotaan.

3. Segmentasi Psikografis

Responden merupakan generasi milenial yang pernah menggunakan batik, aktif menggunakan sosial media, dan tech-savvy. Target pasar memiliki mobilitas yang tinggi di usia produktifnya serta senang bersantai bersama teman atau keluarga. Memiliki ketertarikan dengan fashion atau memperhatikan penampilannya. Senang berbelanja atau konsumtif.

\section{Analisis Ketertarikan Visual Pada Batik Bun- ga Teratai Malangan}

Analisis ketertarikan visual untuk pengembangan batik bunga teratai malangan dilakukan melalui kuesioner yang dijelaskan secara deskriptif. Menggunakan teknik kuesioner yang dilakukan kepada 130 responden. Analisis data dari hasil survei ketertarikan visual menunjukan terdapat 
$71.3 \%$ responden perempuan dan $28.7 \%$ responden laki-laki. Didominasi dengan $84.6 \%$ responden berusia 21-27 tahun dan didukung dengan $15.6 \%$ berusia $28-41$ tahun. Dengan begitu bisa diketahui bahwa kuesioner ini di dominasi oleh generasi milenial akhir. Tingkat Pendidikan responden D4/S1 sebanyak $80.8 \%$ didominasi oleh mahasiswa dan karyawan swasta. Merupakan WNI pada daerah Jakarta sebanyak $36 \%$, Bandung $22 \%$ dan $>7 \%$ Malang.

Analisis ketertarikan responden ini dilakukan terhadap objek tekstil yang merupakan produk tradisional batik bunga teratai malangan yang dibuat oleh pengrajin, dan produk tekstil bunga teratai malangan yang telah mengalami pengembangan tahap 1 oleh peneliti.

Analisis ketertarikan responden ini memiliki 4 variable fokus yang diteliti yaitu, (1) kesan ketertarikan tampilan visual, (2) kesan ketertarikan untuk membeli, (3) kesan kenyamanan saat digunakan, dan (4) kesan harga terhadap visual dan keinginan untuk membeli.

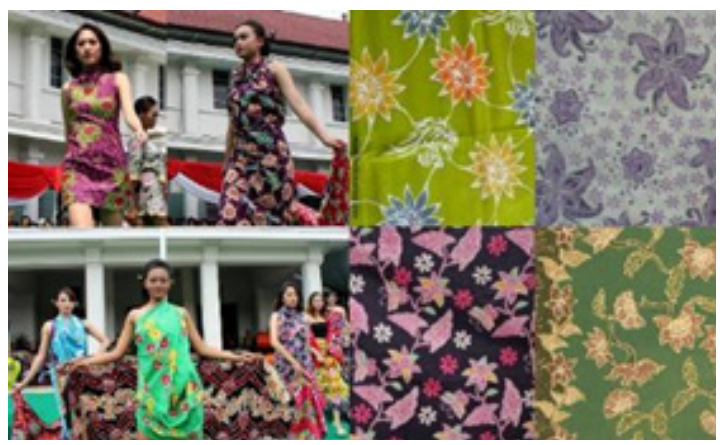

Gambar 10 Komparasi Kreasi Batik Bunga Teratai Malangan Tradisional (Audianty, 2020)

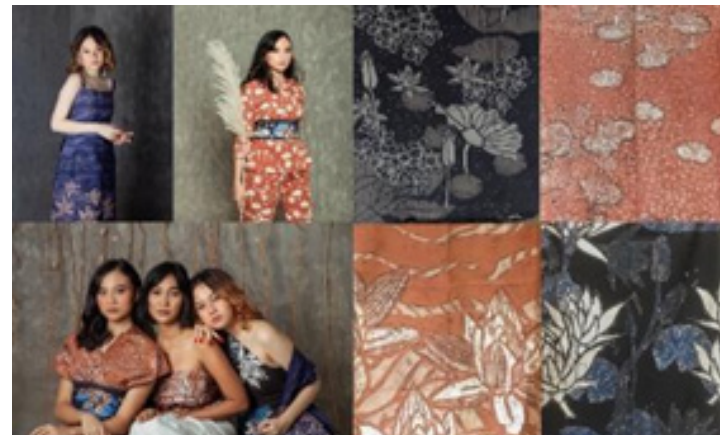

Gambar 11 Komparasi Pengembangan Batik Bunga Teratai Malangan Tahap 1 (Audianty, 2020)

1. Kesan ketertarikan visual

Hasil survey menunjukkan, dari produk yang diperlihatkan kepada responden, tingkat ketertarikan terhadap tampilan visual produk batik tradisional Malang sebanyak $46.2 \%$ tidak tertarik dan dan $53.8 \%$ tertarik Sedangkan hasil survey untuk produk pengembangan tahap 1 batik bunga teratai malangan memperlihatkan bahwa terjadi peningkatan yaitu sebanyak $96.2 \%$ responden tertarik dengan tampilan visual produk pengembangan tahap 1 dan $3.8 \%$ responden tidak tertarik.
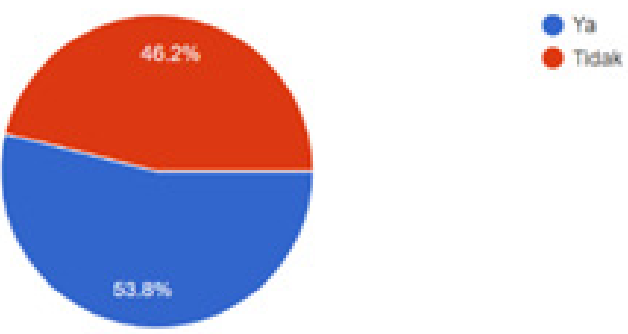

Gambar 12 Diagram Ketertarikan Visual Responden terhadap Batik Tradisional (Audianty, 2021) 


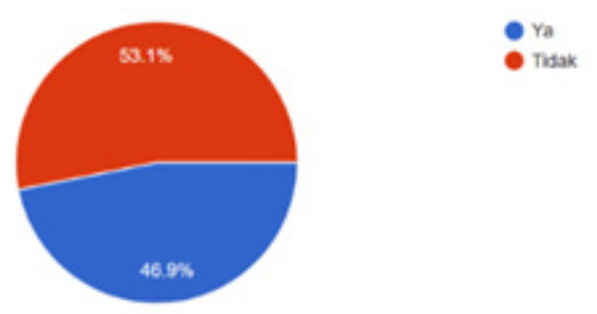

Gambar 13 Diagram Ketertarikan Visual Responden terhadap Batik Tahap 1 (Audianty, 2021)

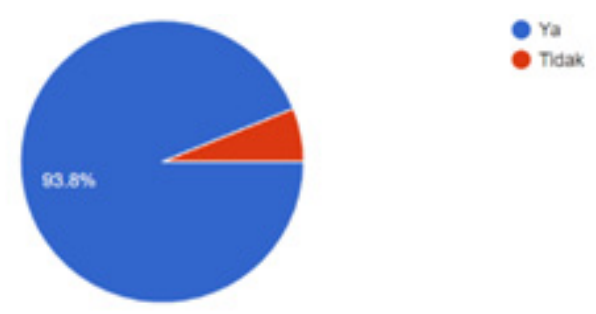

Gambar 14 Diagram Ketertarikan Membeli Responden terhadap Batik Tradisional (Audianty, 2021)

2. Kesan ketertarikan untuk membeli

Ketertarikan responden untuk membeli produk batik tradisional menunjukan bahwa sebanyak $53.1 \%$ tidak tertarik untuk membeli dan $46.9 \%$ lainnya tertarik untuk membeli. Sedangkan terdapat sebanyak $93.8 \%$ responden tertarik untuk membeli produk batik pengembangan tahap 1 , dan $6.2 \%$ tidak tertarik untuk membeli
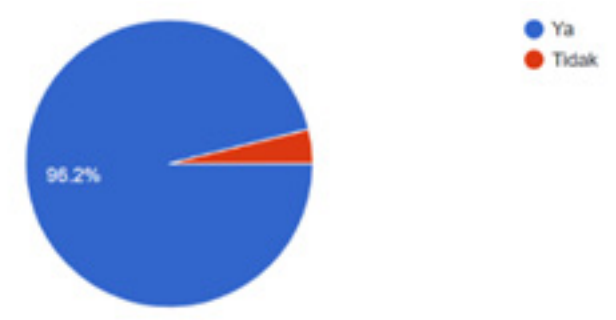

Gambar 15 Diagram Ketertarikan Membeli Responden terhadap Batik Tahap 1 (Audianty, 2021)
3. Kesan kenyamanan

Kesan kenyamanan responden dari produk batik tradisional ini menunjukan $26.2 \%$ responden merasa nyaman menggunakan produk tersebut, sedangkan $54.6 \%$ raguragu dan $19.2 \%$ merasa tidak nyaman menggunakan produk batik tradisional bunga teratai malangan.

Sedangkan kesan kenyamanan responden terhadap pengembangan produk batik tahap 1 ini menunjukan $95.4 \%$ responden merasa nyaman, $0 \%$ ragu-ragu dan $4.6 \%$ merasa tidak nyaman menggunakan produk batik pengembangan tahap 1.
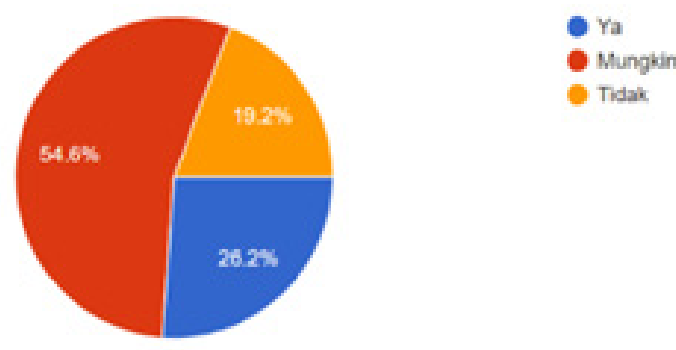

Gambar 16 Diagram Kesan Kenyamanan Responden terhadap Batik Tradisional (Audianty, 2021)

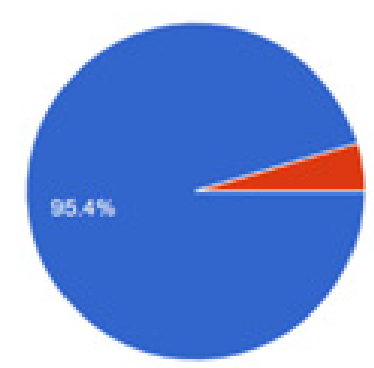

Gambar 17 Diagram Kesan Kenyamanan Responden terhadap Batik Tahap 1 (Audianty, 2021) 


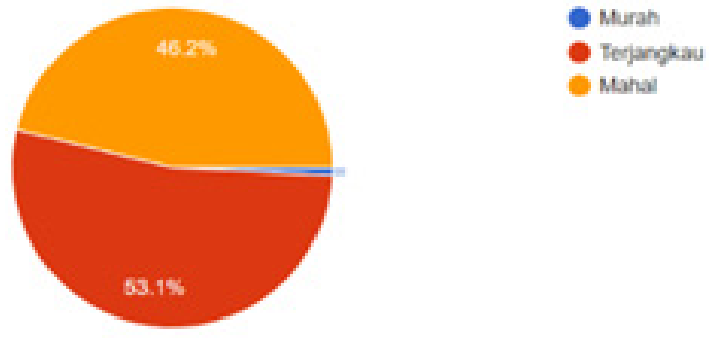

Gambar 18 Diagram Kesan Harga Responden terhadap Batik Tradisional (Audianty, 2021)

4. Kesan harga terhadap visual dan keinginan untuk membeli

Hubungan antara kesan harga dan tampilan visual batik tradisional ini menunjukan bahwa $73.8 \%$ responden mengatakan memiliki harga terjangkau, $6.2 \%$ responden setuju bahwa harga produk ini mahal, dan $20 \%$ lainnya menyatakan murah. Sedangkan tampilan visual batik pengembangan tahap 1 menunjukan bahwa $53.1 \%$ responden mengatakan kesan harga terjangkau, $46,2 \%$ responden setuju bahwa harga produk ini mahal, dan hanya $0.7 \%$ responden yang menyatakan murah.

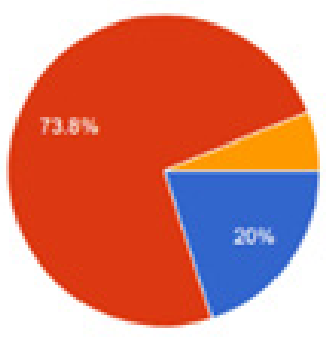

Gambar 19 Diagram Kesan Harga Responden terhadap Batik Tahap 1 (Audianty, 2021)

Dari hasil analisis survei terhadap perbandingan produk batik bunga teratai malangan tradisional dan pengembangan tahap 1 , kemudian di analisis lebih lanjut mengenai variable ketertarikan apa saja yang dapat meningkatkan nilai komersil, nilai daya tarik dari batik bunga teratai malangan sehingga terdapat ketertarikan dari responden untuk membeli produk ini lebih baik dari sebelumnya.

Survey dilakukan kepada 130 responden generasi millenial. Hasil analisis ketertarikan produk batik tekstil ini tebagi menjadi 2 variable yaitu, ketertarikan terhadap tampilan visual desain dan ketertarikan terhadap tampilan produk olahan batik bunga teratai malangan.

1. Pengaruh ketertarikan terhadap tampilan visual desain

Sebanyak $92.3 \%$ responden tertarik pada warna batik, yang ditunjukan dengan adanya pengembangan atau adaptasi warna untuk meningkatkan nilai dari produk batik itu sendiri.

Terdapat sebanyak $83.1 \%$ responden tertarik pada motif sebagai salah satu instrumen yang dapat meningkatkan ketertarikan responden terhadap produk.

Selanjutnya, $66.2 \%$ responden setuju bahwa produk/desain dari batik bunga teratai malangan memiliki pengaruh yang tinggi untuk responden ketika melihat produk terkait.

Didukung dengan ketertarikan responden terhadap komposisi desain sebanyak $56.9 \%$, hal ini menunjukan bahwa pengembangan visual 
pada komposisi desain dapat di eksplorasi lebih lanjut sebagai upaya menngkatkan daya tarik responden.

Tampilan visual lainnya yang menarik bagi responden adalah material / bahan sebanyak $48.2 \%$ dan teknik membatik sebanyak $17.7 \%$.

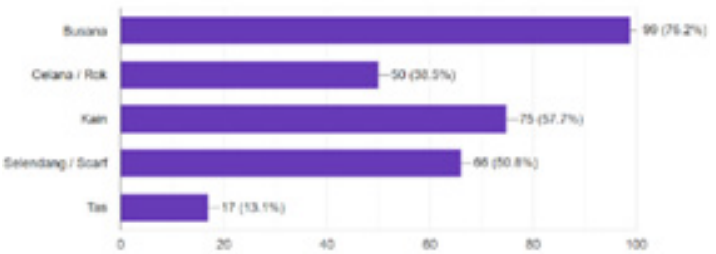

Gambar 20 Diagram Pengaruh Pengembangan Visual Batik (Audianty, 2021)

2. Pengaruh ketertarikan terhadap tampilan produk olahan batik

Terdapat beberapa produk olahan batik yang berpengaruh terhadap ketertarikan responden. Produk olahan yang paling tinggi diminati adalah busana, sebanyak $76.2 \%$. Hal ini dapat ditunjukan karena olahan tekstil yang sering digunakan sehari-hari adalah busana, dapat meliputi kemeja, dress, blouse, dll.

Selanjutnya terdapat $57.7 \%$ responden menyatakan tertarik terhadap olahan produk kain batik. Ditunjukan bahwa banyak responden yang menggunakan kain batik dalam acara formal seperti pernikahan.

Produk olahan yang menarik bagi responden yang ketiga adalah selendang/scarf. Penggunaan selendang atau scarf ditunjukan dengan
$50.8 \%$ responden yang setuju tertarik. Biasanya produk ini menjadi aksesoris fashion untuk wanita dan menjadi item yang mudah di padu-padankan oleh generasi millenial saat ini.

2 olahan produk lainnya yang diminati adalah celana/rok sebanyak $36.5 \%$ dan tas sebanyak $13.1 \%$.

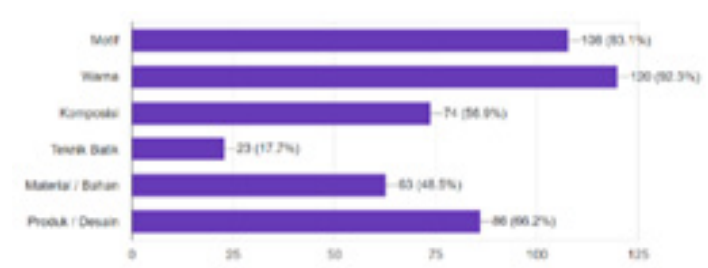

Gambar 21 Diagram Pengaruh Pengembangan Produk Batik (Audianty, 2021)

Dari hasil survei kepada 130 responden diatas, maka potensi ketertarikan generasi milenial terhadap produk batik bunga teratai malangan dapat ditingkatkan dengan mempertimbangkan beberapa variabel. Pengembangan ini perlu didasari dengan adanya pembaharuan terhadap visual dan produk batik dengan mempertimbangkan konsep ATUMICS yang meliputi warna, motif, komposisi, teknik, material, dan desain produk sebelum melakukan eksplorasi lanjutan. Tiga unsur dalam visual desain batik yang paling menarik bagi responden generasi milenial adalah warna, motif, dan desain produk. Sedangkan pengembangan desain produk yang diminati oleh generasi ini yaitu busana, kain, dan selendang/scarf. Prinsip ATUMICS dalam pengembangan produk batik bunga teratai Malangan ini perlu diterapkan supaya kekayaan 
budaya dan tradisi Malang tidak menyalahi aturan yang ada, dan tidak hilang walaupun adanya peleburan dengan modernitas (Nugraha, 2012:205).

Pengembangan batik bunga teratai malangan dapat dilihat peningkatannya dari perbandingan batik tradisional dan batik pengembangan tahap 1. Pemilihan wama dalam pengembangan warna dalam proses eksplorasi batik desain baru dapat diterapkan dengan penggunaan wama soft dan tidak vibrant untuk meningkatkan rasa nyaman pengguna.

Pemilihan warna netral dan earthy juga mudah di padu-padankan oleh generasi milenial sehingga memiliki kesan ethnic modern. Warna netral dan earthy ini tidak terlalu mencolok dan dapat digunakan sehari-hari maupun formal. Pada aspek visual pada motif, kesederhanaan atau motif yang minimalis lebih memiliki ketertarikan yang tinggi dilihat dari ketertarikan generasi milenial lebih tinggi pada produk pengembangan tahap 1. Motif dapat dibuat dengan ukuran kecil-sedang. Dengan tidak terlalu banyak omamen atau latar.

Desain pada produk batik bunga teratai malangan juga menjadi hal penting bagi ketertarikan generasi milenial untuk membeli kerajinan ini. Produk olahan batik yang di minati oleh generasi milenial ini adalah pakaian ready-to-wear yang tetap rapih dan bisa digunakan sehari-hari maupun acara formal. Oleh karena itu, produk batik bunga teratai pada pengembangan tahap 1 lebih memiliki ketertarikan yang tinggi.
Analisis ini menunjukan bahwa batik desain baru untuk pengembangan desain bunga teratai malangan harus melalui eksplorasi lanjutan yang meliputi aspek estetik dalam visual seperti komposisi bentuk, teknik, material, dan warna dalam produk batik (Sachari, 2003:1 dalam Kodiya, 2016). Begitu pula perlu diperhatikan 3 unsur utama dalam estetika batik yaitu wujud/ rupa, isi, dan penyajian produk batik (Kodiya, 2016).

\section{Analisis Potensi Pemasaran Batik untuk Generasi Milenial}

Aspek management dalam UMKM Malang secara garis besar pada tahun 2017 masih sangat sederhana dan konvensional. Sehingga kemampuan untuk mengembangkan usaha ini masih sangat besar dan sulit Hermawati, dkk (2017). Pemasaran produk untuk perputaran ekonomi UMKM masih mengutamakan metode tradisional dari mulut-kemulut sedangkan teknologi pemasaran digital masih minim digunakan. Pemerintah pusat berupaya untuk mendukung kekuatan baru untuk perekonomian di era digital ini yaitu dengan kreatifitas produk, digitalisasi UMKM, dan integrasi keuangan digital yang cepat (Berita satu dalam Fibrianto, 2020).

Konsumer yang menjadi sasaran tepat dalam pengembangan ekonomi UMKM ini adalah generasi milenial. Dari pola ketertarikan dan kebiasaan generasi ini, potensi peningkatan ekonomi melalui pemasaran harus didukung dengan pemasaran yang cepat karena generasi 
ini memiliki karakter konsumtif, efisien, dan mengikuti perkembangan digital yang cepat.

Media digital yang paling banyak diminati atau aktif dalam melakukan pemasaran produk batik malangan untuk generasi milenial berdasarkan hasil analisis adalah Instagram sebanyak $40.8 \%$ dan e-commerce sebanyak 53.1\%.
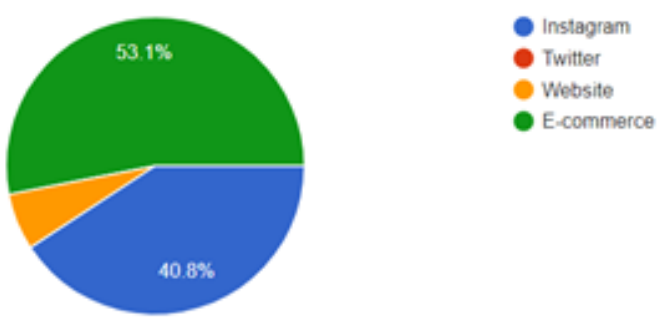

Gambar 22 Diagram Ketertarikan Media Pemasaran Digital Batik (Audianty, 2021)

Hasil survei menujukan bahwa pendapatan ratarata yaitu $\mathrm{Rp}$ 0-5.000.000,-. Dengan begitu, harga yang rela dikeluarkan oleh generasi milenial dari hasil analisis dalam membeli produk batik juga berkisar 100.000-500.000, hal ini terlihat dari $63 \%$ responden menyetujui hal tersebut.

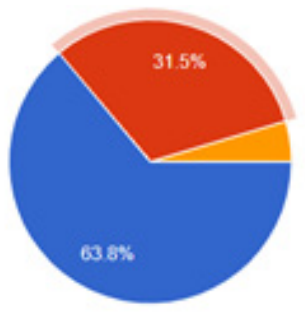

$100.000-500000$ $500.001 \cdot 1.000000$ $>1.000 .001$

Gambar 23 Diagram Ketertarikan Harga Membeli Batik (Audianty, 2021)
Dalam potensi pemasaran untuk meningkatkan daya tarik dan nilai komersil pada produk batik malangan, storytelling dan konsep konten dalam media sosial juga sangat berpengaruh dalam minat beli generasi milenial. Dengan begitu, perlu adanya branding yang unik, sesuai dengan trend, dan pengenalan tentang produk batik bunga teratai malangan yang terkait dengan kearifan lokal daerah, daya tarik wisata, potensi peningkatan ekonomi, dan meningkatnya kehidupan sosial masyarakat melalui pendekatan teknologi yang lebih cepat dan luas. Dengan begitu upaya meningkatkan pengetahuan, nilai komersil, dan daya beli untuk UMKM lebih maksimal.

\section{KESIMPULAN}

Berdasarkan analisis mengenai ketertarikan generasi milenial untuk pengembangan batik bunga teratai malangan, maka dapat ditarik kesimpulan sebagai berikut:

1. Proses revitalisasi tradisi pada sebuah kawasan mencangkup perbaikan berbagai aspek yang harus disertai dengan memanfaatkan potensi daerah dan memperhatikan Artefact, Technique, Utility, Material, Icon, Concept, dan Shape. Selain itu nilai estetik visual dan produk juga menjadi pertimbangan dalam menarik konsumen. Generasi milenial menjadi konsumen yang tepat karena karakternya yang dekat dengan keterbaruan desain, konsumtif, dan perkembangan digital.

2. Potensi lingkungan derah Malang berperan erat dalam proses terbentuknya kesenian 
sehingga sering menjadi inspirasi dalam kreatifitas masyarakat. Pengembangan tersebut terlihat dari penggunaan alat modern, pewarnaan batik, dan usaha mengembangkan variasi motif bunga teratai malangan untuk menciptakan batik desain baru. Pengembangan ini juga meleburkan nilai estetika batik dan keahlian pengrajin batik.

3. Pengembangan batik desain baru dengan motif bunga teratai untuk generasi milenial menunjukan bahwa aspek visual dan desain produk memiliki potensi ketertarikan yang tinggi. Ketertarikan ini dilihat dari perbandingan batik tradisional dan pengembangan batik tahap 1. Aspek visual yang paling menarik bagi generasi milenial adalah warna, motif, dan desain produk. Sedangkan produk fashion tersebut meliputi busana, kain, dan scarf/ selendang. Pengembangan ketertarikan generasi milenial pada visual dan desain produk ini sejalan dengan metode ATUMICS yang tetap menjaga kekayaan budaya daerah. Sehingga pengembangan ini dapat menjadi acuan dalam meningkatkan daya tarik dan nilai komersil untuk masyarakt.

4. Hasil analisis menunjukan bahwa untuk menciptakan batik desain baru motif bunga teratai malangan untuk generasi milenial harus melalui eksplorasi lanjutan yang meliputi aspek estetik dalam visual batik seperti komposisi bentuk, teknik, material, dan warna dalam produk batik. Begitu juga dengan mempertimbangkan wujud, isi, dan penyajian produk batik. Penyajian produk batik juga meliputi produk fashion dan pemasaran produk hingga ke tangan konsumen / generasi milenial. Pemasaran yang banyak diminati yaitu melalui instagram dan e-commerce, hal ini dikarenakan milenial memilik karakter yang efisien, update dengan dunia digital, dan juga konsumtif.

\section{DAFTAR RUJUKAN}

\section{Buku:}

Anas, B., Hasanudin, Panggabean, R., dan Sunarya, Y. (1997) : Indonesia Indah

Anshori, Yusak, dan Adi Kusrianto. 2011. Batik Keeksotisan Batik Jawa Timur : Memahami Motif dan Keunikannya.

Boediono. 2016. Ekonomi Indonesia dalam Lintasan Sejarah. Bandung: Mizan.

Danisworo, Muhammad, dkk. (2000). Revitalisasi Kawasan KotaSebuah Catatan dalam Pengembangan dan Pemanfaatan Kawasan Kota.

Danisworo, Muhammad, dkk. (2012). Revitalisasi Ditinjau dari Berbagai Sudut Pandang.

Djelantik, AAM. (1999) : Estetika Sebuah Pengantar.

Gaut, Berys \& Dominic Lopes. 2000. The Routledge Companion to Aesthetics

Kupperschmidt BR. 2000. Multigeneration employees: strategies for effective management. The Health CareManager

Kusrianto, Adi. 2013. Batik Filosofi, Motif \& Kegunaan.

Kodiya, Komarudin. 2016. Revitalisasi Batik Lama Keraton-Keraton Cirebon Dengan 
Ragam Hias Taman Telaga Teratai Sebagai Wujud Refleksi Integrasi Budaya.

Nugraha, Adhi. 2012. Transforming Tradition. Helsinki: Unigrafia

Sachari dan Sunarya. 1993. PENGANTAR TINJAUAN DESAIN. Penerbit: Institut Teknologi Bandung.

Sachari, A. (2003). Peran dan makna nilai estetis modern dalamperkembangan desain abad-20 di indonesia

Sunarya, Yan Yan. 2014. Strategi Adaptasi Visual Pada Ragam Hias Batik Sunda.

Jurnal:

Anas, B. (2007) : Pendidikan Tinggi Kri(y)a Dalam Wahana Tradisi, Sebuah Tawaran Konteks, Makalah Seminar Nasional Paradigma Pendidikan Seni Rupa di Masa Mendatang.

Handinoto dan Soehargo, paulus H. 1996.

Perkembangan Kota dan Arsitektur Kolinial Belanda di Malang. Yogyakarta : Andi.

Hermawati, Adya dkk. 2017. Strategi Bersaing :

Batik Malangan Konvensional melalui Diversifikasi Produk Batik Kombinasi pada UKM Kelurahan Merjosari Malang. Jurnal IImiah Bisnis dan Ekonomi Asia.

Lancaster, L. C. and Stillman, D. (2002). When Generations Collide. Who They Are. Why They Clash. How to Solve the Generational Puzzle at Work. New York: Collins Business.
Lyons, S. (2004). An exploration of generational values in life and at work. ProQuest Dissertations and Theses, 441-441.

Parry, E., \& Urwin, P. (2010). Generational differences in work values: A review of theory and evidence. International Journal of Management Reviews, 13, 79-96.

Internet:

Adhisakti, Laretna T, 2005. Revitalisasi Kawasan Pusaka di Berbagai Belahan Bumi, Harian Kompas (Diakses: 17 Maret 2021)

Berita Satu. Fibrianto, Didik. BI Mendorong UMKM di Malang Go Digital. https:// www.beritasatu.com/ekonomi/700851/ bi-mendorong-umkm-di-malang-godigital (Diakses: 15 Maret 2021)

Berita Satu. Herman / FMB. 2020. Generasi Milenial Jadi Sumber Kekuatan UMKM Indonesia. https://www.beritasatu.com/ ekonomi/700723/generasi-milenialjadi-sumber-kekuatan-umkm-indonesia (Diakses: 17 Maret 2021)

Bidang Informasi Publik. 8 September 2019. Sukses Tingkatkan Sektor UMKM, Kota Malang Terima Penghargaan Natamukti. https://malangkota.go.id/2019/. (Diakses: 20 Janurari 2021)

Pemerintah Kota Malang. 2020. Sejarah Malang. https://malangkota.go.id/sekilas-malang/ sejarah-malang/. (Diakses: 20 Janurari 2021) 
Yuswohady. (2016). Millennial Trends 2016. http://www.yuswohady.com/2016/01/17/ millennial-trends-2016/. (Diakses: 17 Maret 2021)

\section{Daftar Narasumber/Informan}

Ibu Bambang Yagasu dan Mba Yanti, Pemilik, Pengrajin Batik Organik Buring Malang, dan Bendahara Asosiasi Pengrajin Jawa Timur

Ibu Ima, Pemilik dan pengrajin Batik Blimbing Malang, Jawa Timur 